\title{
HUBUNGAN STATUS EKONOMI DENGAN KEJADIAN ANEMIA PADA IBU HAMIL TRIMESTER III DI PUSKESMAS BERNUNG PESAWARAN
}

\section{RELATIONSHIP OF ECONOMIC STATUS WITH ANEMIA OCCURRENCE IN PREGNANT WOMAN TRIMESTER III AT PUBLIC HEALTH CENTER BERNUNG PESAWARAN}

\author{
Yeti Septiasari \\ STIKes Muhammadiyah Pringsewu
}

\begin{abstract}
ABSTRAK
Anemia pada kehamilan merupakan indikator kesehatan yang buruk. Penyebab utama dari kejadian anemia merupakan asupan makanan yang tidak memadai yang dilatar belakangi dari pendapatan keluara. Penelitian ini bertujuan untuk melihat hubungan statsu ekonomi dengan kejadian anemia pada ibu hamil Trimester III di Puskesmas Bernung Kabupaten Pesawaran.Penelitian ini menggunakan desain analitikdengan pendekatan cross sectional. Populasi target pada penelitian ini adalah seluruh ibu hamil di Wilayah Puskesma Bernunng. Sampel pada penelitian ini adalah ibu hamil Trimester III yang datang ke Puskesmas Bernung yang telah memenuhi kriteria inklusi dan eksklusi dengan jumlah 87 orang. Hasil diperoleh bahwa ada sebanyak 25 orang $(61,0 \%)$ ibu yang berpenghasilan < UMP mengalami anemia. Hasil uji statistik chi square menunjukkan bahwa nilai $\mathrm{p}=$ $0,005$ ( $\mathrm{p} \leq 0,05)$, RP 3,460 (95\% CI = 1,421 - 8,425), maka dapat disimpulkan ibu dengan berpenghasilan < UMP meningkatkan kejadian anemia sebesar 3,4 kali dibandingakn dengan ibu dengan berpenghasilan >UMP. Disarankan pada ibu hamil dengan status ekonomi yang berisiko untuk rutin melakukan kunjungan antenatal, mendapatkan pendidikan kesehatan agar dapat mengkomsumsi tablet Fe dan makanan bergizi dengan harga murah.
\end{abstract}

Kata kunci : anemia ibu hamil, status ekonomi

\begin{abstract}
Anemia in pregnancy is a poor indicator of health. The main cause of the incidence of anemia is an inadequate food intake from the background of income. This study aims to see the relationship of economic statsu with the incidence of anemia in pregnant women Trimester III at Bernung District Health Center Pesawaran.This research used analytic design with cross sectional approach. The target population in this study was all pregnant women in the PuskesmaBernunng Area. The sample in this research is pregnant mother of Trimester III who come to Bernung Public Health Center which has fulfilled inclusion and exclusion criteria with 87 people. The result the incidence of anemia in pregnant women found that there were 25 people $(61.0 \%)$ of mothers who earned below standart had anemia. The result of chi square statistic test shows that $\mathrm{p}=0,005(\mathrm{p} \leq 0,05), \mathrm{RP} 3,460(95 \% \mathrm{CI}=$ 1,421 - 8,425), it can be concluded that mother with income <UMP increase incidence of anemia 3,4 times compared with mother with income> UMP. It is recommended that pregnant women with at-risk economic status perform routine antenatal visits, get health education in order to consume Fe tablets and nutritious food at low prices
\end{abstract}

Keywords: maternal anemia, economic status 


\section{PENDAHULUAN}

Anemia dalam kehamilan adalah kondisi ibu dengan kadar hemoglobin $(\mathrm{Hb})$ < 11 gr\% pada trimester I dan III sedangkan pada trimester II kadar hemoglobin < 10,5 gr\%. Anemia kehamilan di sebut "potentional danger to mother and child" (potensi membahayakan ibu dan anak), karena itulah anemia memerlukan perhatian serius dari semua pihak yang terkait dalam pelayanan kesehatan ${ }^{1,2}$.

Penyebab anemia pada ibu hamil adalah kekurangan zat besi dalam tubuh. Anemia defisiensi zat besi merupakan anemia yang disebabkan oleh kurangnya zat besi, asam folat dan vitamin B12 di karenakan asupan yang tidak adekuat atau ketersediaan zat besi yang rendah $^{3}$.

Wanita hamil sangat rentan terjadi anemia defisiensi besi karena pada kehamilan kebutuhan oksigen lebih tinggi sehingga memicu peningkatan produksi eritropoietin. Akibatnya, volume plasma bertambah dan sel darah merah (eritrosit) meningkat. Namun peningkatan volume plasma terjadi dalam proporsi yang lebih besar jika dibandingkan dengan peningkatan eritrosit sehingga penurunan konsentrasi hemoglobin $(\mathrm{Hb})$ akibat hemodilusi ${ }^{4}$.

Faktor resiko terjadinya anemia dimulai dari politik ekonomi negara yang dipengaruhi oleh ekologi, iklim dan geografi. Ekonomi Negara dapat mempengaruhi pendidikan, pendapatan, budaya dan perilaku yang akan berdampak pada subyek rentan seperti ibu hamil dan paritas tinggi. Hal tersebutlah yang akan mempengaruhi akses keanekaragaman pangan, akses sumber fortifikasi, akses pengetahuan terhadap anemia, akses air bersih dan sanitasi serta akses terhadap kesehatan. Rendahnya akses tersebut akan menyebabkan asupan nutrisi dan penyerapan yang tidak adekuat dan menurunkan produksi sel darah merah yang menyebabkan anemia ${ }^{5}$.

Menurut Riskesdas (2013) Secara nasional, proporsi anemia pada ibu hamil sebesar $37,1 \%$, dan prevalensinya hampir sama antara bumil di perkotaan $(36,4 \%)$ dan perdesaan (37,8\%). Hal ini menunjukkan angka tersebut mendekati masalah kesehatan masyarakat berat (severe public health problem) dengan batas prevalensi anemia $\geq 40 \%{ }^{6}$

Puskesmas Bernung terletak di Kabupaten Pesawaran yang adalah salah satu Kabupaten Kota di Provinsi Lampung. Puskesmas Bernung telah didukung oleh sarana kesehatan yang lebih baik untuk pelayanan KIA. Mayoritas ibu hamil yang berdomisili di Wilayah kerja Puskesmas Bernung memeriksakan kehamilannya di Puskesmas Bernung. Semua ibu hamil yang memeriksakan kehamilannya mendapatkan tablet tablet besi sesuai usia kehamilannya. Salah satu factor yang menyebabkan masih 
tingginya angka kejadian anemia adalah rendahnya kepatuhan ibu hamil dalam mengkonsumsi tablet Fe. Data anemia di Dinas Kesehatan Kabupaten Pesawaran diperoleh data yaitu ibu hamil yang melakukan pemeriksaan sebanyak $6454 \mathrm{ibu}$ hamil dari jumlah kunjungan 8.831 sedangkan ibu hamil yang mengalami anemia yaitu sebanyak 1675 atau sekitar 26 $\%$ dari total kehamilan dan puskesmas yang tertinggi yaitu Puskesmas Bernung yaitu sebesar 18,6 \%.Sedangkan data ibu hamil yang mengalami anemia pada tahun 2015 yaitu sebanyak 3.275 kasus $(49,3 \%)$ dari 6632 ibu hamil dari jumlah kunjungan 9.213, dimana kasus tertinggi terdapat pada Puskesmas Bernung sebanyak 565 kasus ${ }^{7}$.

Penelitian ini bertujuan untuk mengetahui hubungan antara status ekonomi dengan kejadian anemia pada ibu hamil TM III di Puskesmas Berung Pesawaran, untuk mengetahui apakkah status ekonomi menjadi salah satu penyebab anemia pada ibu

\section{METODE}

Penelitian ini menggunakan rancangan observasional analitik dengan pendekatan crossectional. Populasi yang diambil dalam penelitian ini adalah ibu hamil trimester III di Puskesmas Bernung Pesawaran. Jumlah sampel dalam penelitian ini yaitu 86 orang. Kriteria yang diambil oleh peneliti sebagai sampel dalam penelitian ini adalah : seluruh ibu hamil trimester III yang sudah mendapat $\mathrm{Fe} 3$ dari tenaga kesehatan, bersedia dan mau menjadi responden, bertempat tinggal diwilayah Bernung Kabupaten Pesawaran. Kegiatan penelitian ini dilaksanakan pada 3- 26 Mei 2016.

\section{HASIL}

\section{Analisis Univariat}

Analisis univariat dilakukan terhadap setiap variabel penelitian ,pada analisis ini akan menghasilkan distribusi frekuensi dari tiap variabel..

\section{a. Status Ekonomi}

Tabel 1 :Distribusi Frekuensi status ekonomi pada ibu hamil Trimester III di Puskesmas Bernung Pesawaran

\begin{tabular}{lcc}
\hline Status Ekonomi & Frekuensi & Presentase \\
\hline$<$ UMP & 39 & 45,3 \\
$>$ UMP & 47 & 54,7 \\
\hline Total & $\mathbf{8 6}$ & $\mathbf{1 0 0}$ \\
\hline
\end{tabular}

Berdasarkan tabel 1, diketahui bahwa responden yang Tingkat ekonomi ibu dimana kategori > UMP 55,7\% dan yang <UMP sebesar $45.3 \%$.

\section{b. Kejadian anemia}

Tabel 2 : Distribusi Frekuensi kejadian anemia pada ibu hamil Trimester III di Puskesmas Bernung Pesawaran.

\begin{tabular}{lcc}
\hline \multicolumn{1}{c}{ Kadar Hb } & Frekuensi & Presentase \\
\hline Tidak anemia & 45 & 52,3 \\
Anemia & 41 & 47,7 \\
\hline Total & $\mathbf{8 6}$ & $\mathbf{1 0 0}$ \\
\hline
\end{tabular}


Berdasarkan tabel 2 diatas dapat dijelaskan bahwa dari 86 responden terdapat $47 \%$ yang mengalami anemia, dan sebesar $52,3 \%$. yang tidak mengalami anemia.

\section{Analisis Bivariat}

Analisis ini digunakan untuk melihat Hubungan Status ekonomi dengan kejadian anemia pada ibu hamil Trimester III di Puskesmas Bernung Pesawaran, maka dilakukan analisis uji chi square dengan CI 95\% dan $\alpha=0,05$ dapat dilihat pada tabel berikut:

Tabel 3 : Hubungan Status ekonomi dengan kejadian anemia pada ibu hamil Trimester III di Puskesmas Bernung Pesawaran

\begin{tabular}{|c|c|c|c|c|c|c|c|c|}
\hline & \multicolumn{6}{|c|}{ Kadar $\mathrm{Hb}$} & Total- & OR \\
\hline \multirow[t]{2}{*}{$\begin{array}{l}\text { Status } \\
\text { ekonomi }\end{array}$} & \multicolumn{2}{|c|}{$\begin{array}{l}\text { Tidak } \\
\text { anamia }\end{array}$} & \multicolumn{2}{|c|}{ Anamia } & \multirow[t]{2}{*}{$\mathrm{n}$} & \multirow[t]{2}{*}{$\%$} & & \\
\hline & $\mathrm{n}$ & $\%$ & $\mathrm{n}$ & $\%$ & & & & \\
\hline$<$ UMP & 25 & $\begin{array}{l}61 \\
39\end{array}$ & 14 & 31,1 & 39 & 100 & $<0,005$ & $\begin{array}{c}3,46 \\
(1,421-\end{array}$ \\
\hline$>\mathrm{UMP}$ & 16 & .0 & 31 & 68,9 & 47 & 100 & & $8,425)$ \\
\hline \multicolumn{6}{|c|}{ TOTAL } & 100 & & \\
\hline
\end{tabular}

Keterangan uji: *Chi Square

Hasil analisis hubungan antara status ekonomi dengan kejadian anemia pada ibu hamil diperoleh bahwa ada sebanyak 25 dari 39 orang ( 61,0\%) ibu yang berpenghasilan < UMP mengalami anemia, sedangkan diantara ibu hamil yang berpenghasilan $\geq$ UMP ada sebanyak 16 dari 47 orang $(39,0 \%)$ mengalami anemia. Hasil uji statistik chi square menunjukkan bahwa nilai $\mathrm{p}=0,005(\mathrm{p} \leq 0,05), \mathrm{RP} 3,460$ $(95 \% \mathrm{CI}=1,421-8,425)$, maka dapat disimpulkan ibu dengan berpenghasilan < UMP meningkatkan kejadian anemia sebesar 3,4 kali dibandingakn dengan ibu dengan berpenghasilan >UMP.

\section{PEMBAHASAN}

Berdasarkan hasil penelitian terhadap sampel penelitian didapatkan analisis univariat yang disajikan dalam bentuk distribusi frekuensi. Tabel ini menjelaskan tentang karakteristik sampel penelitian pada ibu hamil. Pada bahasan ini akan memberikan gambaran tentang kondisi ibu hamil di wilayah Puskesmas Bernung Pesawaran.

\section{Status Ekonomi}

Tingkat ekonomi ibu dimana kategori >UMP 55,7\% dan yang <UMP sebesar $45.3 \%$. Status ekonomi keluarga biasanya memiliki pengaruh buruk terhadap prilaku kesehatan. Keluarga mungkin tidak mampu membeli makanan, perawatan kesehatan dan perumahan, atau memiliki sanitasi yang buruk. Status ekonomi keluarga yang rendah mempengaruhi prilaku kesehatan seperti tidak diimunisasi terhadap penyakit menular ${ }^{8}$.

Di Indonesia pendapatan dilihat dari Upah Minimum Regional. Upah Minimum Regional adalah suatu standar minimum yang digunakan oleh para pengusaha atau pelaku industri untuk memberikan upah 
kepada pegawai, karyawan atau buruh di dalam lingkungan usaha atau kerjanya. Pemerintah mengatur pengupahan melalui Peraturan Menteri Tenaga Kerja No. 05/Men/1989 tanggal 29 Mei 1989 tentang Upah Minimum ${ }^{9}$.

\section{Kejadian Anemia Dalam Kehamilan}

Pada kehamilan volume darah bertambahn banyak pada waktu kehamilan yang lazim disebut hydremia atau hipervolemia. Volume darah ibu bertambah lebih kurang $50 \%$ yang menyebabkan konsentrasi sel darah merah mengalami penurunan. Keadaan ini tidak normal bila konsentrasi turun terlalu rendah yang menyebabkan $\mathrm{Hb}$ sampai < 11 gr $\%$. Meningkatnya volume darah berarti meningkat pula jumlah zat besi yang dibutuhkan untuk memproduksi sel - sel darah merah sebagai kompensasai tubuh untuk menormalkan konsentrasi haemoglobin ${ }^{4}$.

Pada kehamilan foetus menggunakan sel darah merah ibu untuk pertumbuhan dan perkembangan terutama pada tiga bulan terakhir kehamilan. Bila ibu telah mempunyai banyak cadangan zat besi dalam sumsum tulang sebelum hamil maka pada waktu kehamilan dapat digunakan untuk kebutuhan bayinya ${ }^{4}$.

Akan tetapi bila pembentukan sel sel darah kurang dibandingkan dengan bertambahnya plasma sehingga terjadi pengenceran darah yang menyebabkan konsentrasi atau kadar haemoglobin tidak dapat mencapai normal sehingga akan terjadi anemia. Keadaan ini dapat terjadi sejak umur kehamilan 10 minggu dan mencapai puncaknya dalam kehamilan 32 36 minggu $^{2}$.

Dari tabel diatas dapat dijelaskan bahwa dari 86 responden terdapat $47 \%$ yang mengalami anemia, dan 52,3\%. yang tidak mengalami anemia sebesar. Tingginya prevalensi anemia pada ibu hamil di Puskesmas Bernung, menunjukkan prevalensi yang lebih tinggi dari angka nasional Riskesdas tahun 2013 yaitu 37,1\% Prevalensi yang melebihi $40 \%$ ini, berdasarkan data WHO merupakan prevalensi yang menandakan permasalah yang besar di wilayahnya ${ }^{10}$.

\section{Hubungan Status Ekonomi Dengan Kejadian Anemia}

Hasil analisis hubungan antara status ekonomi dengan kejadian anemia pada ibu hamil diperoleh bahwa ada sebanyak 25 dari 39 orang ( 61,0\%) ibu yang berpenghasilan < UMP mengalami anemia, sedangkan diantara ibu hamil yang berpenghasilan $\geq$ UMP ada sebanyak 16 dari 47 orang $(39,0 \%)$ mengalami anemia. Hasil uji statistik chi square menunjukkan bahwa nilai $\mathrm{p}=0,005(\mathrm{p} \leq 0,05), \mathrm{RP} 3,460$ $(95 \% \mathrm{CI}=1,421-8,425), \quad$ maka dapat disimpulkan ibu dengan berpenghasilan < 
UMP meningkatkan kejadian anemia sebesar 3,4 kali dibandingakn dengan ibu dengan berpenghasilan > UMP. ${ }^{9}$

Perilaku seseorang dibidang kesehatan dipengaruhi oleh latar belakang sosial ekonomi. Pendapatan berkaitan erat dengan status ekonomi. Status ekonomi adalah kedudukan atau posisi seseorang dalam masyarakat yang menggambarkan pendapatan per bulan yang disesuaikan dengan harga barang pokok ${ }^{11}$.

Menurut WHO anemia disebabkan oleh kekurangan zat besi, kekurangan asam folat, kekurangan vitamin B12, supresi sum-sum tulang belakang, penyakit hemolitik seperti malaria dan sickle cell dan kanker ganas, serta kehilangan darah kronis seperti cacingan. Penyakit anemia lebih sering dijumpai pada wanita miskin dan dipengaruhi oleh kebiasaan makan ${ }^{12}$.

Prevalensi anemia lebih besar pada ibu hamil dengan kondisi pendapatan lebih rendah dari Upah Minimum Regional (UMR). Hal ini berpengaruh terhadap daya beli makanan yang dikonsumsi oleh keluarga karena $>57 \%$ penghasilan keluarga di habiskan untuk keperluan pembelian makan. Kondisi ini yang menyebabkan ibu dengan keluarga pendapatan rendah tidak mendapat nutrisi yang adekuat sehingga berisiko terjadinya anemia ${ }^{11}$.

Jumlah keluarga akan mempengaruhi jumlah distribusi makanan dalam keluarga. Ibu hamil dengan keluarga yang besar akan lebih mudah anemia karena jumlah makan harus dibagi dengan keluarga lainnya, hal ini diperparah bila jumlah makanan tidak mencukupi bagi keluarga karena ekonomi kurang yang akan berdampak kekurangan nutrisi ${ }^{11}$.

Kurangnya pendapatan keluarga menyebabkan berkurangnya lokasi dan untuk pembelian makanan sehari-hari sehingga mengurangi jumlah dan kualitas makanan ibu perhari yang berdampak pada penurunan status gizi. Gangguan gizi yang umum pada wanita hamil adalah anemia. Sumber makanan yang diperlukan untuk mencegah anemia umumnya berasal dari sumber protein yang lebih mahal dan sulit terjangkau oleh mereka yang berpenghasilan rendah. Kekurangan tersebut memperbesar resiko anemia pada ibu hamil serta mempercepat resiko kesakitan pada ibu ${ }^{13}$.

Ibu hamil dengan status ekonomi rendah lebih berisiko terjadinya anemia. Hal ini berhubungan dengan daya beli masyarakat. Konseling yang diberikan adalah untuk meningkatkan kepatuhan dalam konsusmi tablet fe dan memilih makanan yang mengandung protein tinggi dengan harga yang murah

\section{SIMPULAN}

Pada temuan penelitian kami, terdapat hubungan yang signifikan status 
ekonomi dengan kejadian anemia pada ibu hamil di Puskesmas Bernung Pesawaran.

\section{DAFTAR PUSTAKA}

1. Bobak. Buku Ajar Keperawatan Maternitas Edisi 4. Jakarta: EGC; 2010.

2. Manuaba IGB. Ilmu Kebidanan, Penyakit Kandungan dan Keluarga Berencana. Jakarta: EGC; 2012.

3. Arisman. Gizi Dalam Daur Kehidupan. Jakarta: EGC; 2009.

4. Winkjosatro H. Ilmu Kebidanan. Jakarta: Yayasan Bina Pustaka; 2010.

5. Balarajan, Ramakrishnan U, Ozaltin E, Shankar AH, Subramanian SV. Anemia in Low-Income and Middle Income Countries. Lancet. 2011;378(12):2123.

6. Riskesdas. Riset Kesehatan Dasar. Jakarta: Kementrian Kesehatan RI, 2013.

7. Dinas Kesehatan. Profil Dinas Kesehatan Kabupaten Pesawaran. 2015.
8. Ricci SS. Essentials Of Maternity, Newborn, And Women's Health Nursing. . New York: Wolters Kluwer; 2008.

9. Penetapan Upah Minimum Provinsi (UMP) (2016).

10. WHO. Daily Iron and Folic Acid Supplement in pregnant Women. In: Organization WH, editor. Geneva2012.

11. Melku M, Assis Z, Alem M, Enawgaw B. Prevalence and Preditors of Maternal Anemia During Pregnancy in Gondar, Northwest Ethiopia: An Institusional Based Cross-Sectional Study. Hindawi Publishing Corporation. 2014;2014:9.

12. Garg A, Kashyap S. Effect of Counseling on Nutritional Status During Pregnancy. Indian J Med Res. 2006;73(8):6.

13. Noverstiti. Faktor - Faktoryang Berhubungan dengan Kejadian Anemia pada Ibu Hamil Trimester III di Wilayah Kerja Puskesmas Air Dingin Kota Padang Tahun 2012. Padang: Univaersitas Andalas; 2012. 